\title{
Investigation of Antibacterial Activities of Ethanol and Methanol Extracts of Some Marine Algae Species on Yersinia ruckeri
}

\author{
Jale KORUN', Emine Şükran OKUDAN'1, Remziye Eda YARDIMCI², Gülşen TIMUR², \\ Aycan ULUTAŞ', Mehmet GÖKOĞLU1, Yağmur Saadet ÇELİK'1, Beytullah Ahmet BALCI ${ }^{1}$ \\ 1 Akdeniz University, Faculty of Fisheries Campus, Antalya, Turkey \\ 2Istanbul University, Faculty of Fisheries Laleli, Istanbul, Turkey
}

\begin{abstract}
In this study, antibacterial activities of extracts of Liagora ceranoides (Rhodophyta), Halopteris scoparia (Ocrophyta), Padina pavonica (Ocrophyta) and Sargassum vulgare (Ocrophyta) on Yersinia ruckeri strains isolated from sick rainbow trout (Oncorbynhus mykiss) were evaluated. Also, susceptibilities of the strains against various antibiotics were studied. The strains isolated from the sick fish were identified as Yersinia ruckeri according to the results of the phenotypic tests, the API 20E rapid diagnostic kit and PCR. In the study, it was found that the methanol extracts of L. ceranoides, H. scoparia, P. pavonica and S. vulgare did not show antibacterial activity against $Y$. ruckeri. The ethanol extract of $P$. pavonica showed low antibacterial activity against $Y$. ruckeri. The ethanol extracts of $L$. ceranoides, H. scoparia and S. vulgare macroalgae did not show antibacterial activity against the bacterium. According to the results of the antibiogram test, it was found that the strains were sensitive against ampicillin, flumequine, oxytetracycline and trimethoprime. The strains showed intermediate resistance against erythromycine. In conclusion, although it was reported that algae had antibacterial activities, it was understood that every algae species could not exhibit antibacterial activity.
\end{abstract}

Keywords: Rainbow trout, Yersinia ruckeri, marine algae, antibacterial activity

\section{Bazı Deniz Alg Türlerinin Etanol ve Metanol Ekstraktlarının Antibakteriyel Aktivitelerinin Yersinia ruckeri Üzerinde Araştırılması}

ÖZ

Bu çalş̧mada Liagora ceranoides (Rhodophyta), Halopteris scoparia (Ocrophyta), Padina pavonica (Ocrophyta) ve Sargassum vulgare (Ocrophyta) alglerinin etanol ve metanol ekstraktlarının hasta gökkuşağ1 alabalığ1 (Oncorbynhus mykiss)'ndan izole edilen Yersinia ruckeri suşları üzerine antibakteriyel aktiviteleri değerlendirilmiştir. Ayrıca, suşların çeşitli antibiyotiklere duyarlılıkları da çalışılmıstır. Balıklardan izole edilen suşlar fenotipik testler, API 20E hızlı tanı kiti ve PZR sonuçlarına göre Yersinia ruckeri olarak tanımlanmıştır. Çalışmada $L$. ceranoides, H. scoparia, $P$. pavonica ve S. vulgare makroalglerinin metanol ekstraktlarının $Y$. ruckerr’ye karşı antibakteriyel etki göstermediği bulunmuştur. $P$. pavonica'nın etanol ekstraktı $Y$. ruckerr’ye karşı düşük antibakteriyel aktivite göstermiştir. $L$. ceranoides, H. scoparia ve $S$. vulgare makroalglerinin etanol ekstraktlarının bakteriye karşı antibakteriyel aktivite göstermediği tespit edilmiştir. Antibiyogram test sonuçlarına göre suşların ampisilin, flumekuin, oksitetrasiklin ve trimetoprime duyarlı oldukları bulunmuştur. Suşlar eritromisine karşı orta derecede direnç göstermiştir. Sonuç olarak, alglerin antibakteriyel aktiviteye sahip olduklarının bildirilmesine karşın her alg türünün antibakteriyel aktivite gösteremeyeceği anlaşılmıştır.

Anahtar Kelimeler: Gökkuşağı alabalığı, Yersinia ruckeri, deniz algleri, antibakteriyel aktivite

To cite this article: Korun J. Okudan E.S. Yardmon R.E. Timur G. Ulutaș A. Gökoğlu M. Celik Y.S. Balcı B.A. Investigation of Antibacterial Activities of Ethanol and Methanol Extracts of Some Marine Algae Species on Yersinia ruckeri. Kocatepe Vet J. (2019) 12(3):226-234

Submission: 06.02 .2019

Accepted: 09.06.2019

Published Online: 20.07 .2019

ORCID ID; JK: 0000-0002-1930-9978, EŞO: 0000-0001-5309-7238, REY: 0000-0001-7737-8739,

AU: 0000-0002-4892-6326, MG: 0000-0001-9723-8581, YSC: 0000-0003-2877-0915, BAB: 0000-0002-6762-3259

*Corresponding author e-mail: jalekorun@akdeniz.edu.tr 


\section{GİRİŞ}

Su ürünleri yetiştiriciliği hızlı gelişme gösteren g1da sektörleri arasında yer almakta olup, dünya genelinde tüketilen balığın yaklaşık olarak \%50'si yetiştiricilik yolu ile sağlanmaktadır. Kültür koşullarında görülen bulaşıc1 hastalıklar ise sektörün gelişmesine engel olmakla birlikte, birçok ülkenin ekonomik gelişimi üzerinde önemli bir etki yapmaktadır (Kumar ve ark 2015). Bakteriyel enfeksiyonlar ciddi epidemiyolojik faktör olup, gökkuşağ1 alabalığ1 kültüründe önemli balık kayıplarına sebep olur (Gohari ve ark 2010, Orozova ve ark 2014). Enterik kızılağız hastalığ1 (ERM) ya da diğer ismi ile yersiniozis balıkların sistemik bakteriyel bir enfeksiyonudur. Hastalık etkeni Yersinia ruckeridir. Etken, ilk olarak 1950'li yılların başında ABD Idaho Hagerman Vadisi'nde yer alan bir alabalık kuluçkahanesindeki hasta balıklardan izole edilmiştir (Horne ve Barnes 1999, Orozova ve ark 2014). Y. ruckerinin bu ilk izolasyonundan sonra, bakteri başta Alaska olmak üzere ABD'nin batı bölgesi ile Kanada'dan bildirilmiştir. Avrupa da ise $Y$. ruckeri ilk kez 1983 yllında bildirilmiş, daha sonraları Danimarka, Fransa, Almanya, İtalya, Norveç, Birleşik Krallık, Yeni Zelanda ve Afrika olmak üzere birçok ülkeye yayılmış ve salmonid balık türlerinin yanı sıra Nil tilapyas1 (Oreochromis niloticus), kalkan (Scophthalmus maximus), sazan (Cyprinus carpio), Avrupa yilan baliğ1 (Anguilla anguilla) ve Avrupa deniz levreği (Dicentrarchus labrax) dahil doğal ve kültürü yapilan çeşitli balık türlerinden de izole edilmiştir (Huang ve ark 2013, Zorriehzahra ve ark 2017). Ülkemizde ise ilk Y. ruckeri kaynaklı hastalık vakası 1991 y1linda bildirilmiştir (Timur ve Timur 1991). Alabalık kültürünün yaygınlaşması ile birlikte, hastalık çıkışlarında da artış yaşanmıştır (Şeker ve ark 2011, Öztürk ve Altınok 2014). Y. ruckeri Gram-negatif, çomak şekilli, sitokrom oksidaz negatif, katalaz pozitif, fermentatif bir bakteri türüdür. Tür çoğunlukla hareketli olmakla birlikte, hareketlilik özelliği suşlara bağlı olarak değişiklik göstermektedir (Fouz ve ark 2006, Zorriehzahra ve ark 2017). ERM tüm yaş gruplarındaki balıkları etkilemekle birlikte, hastalığın akut formu çoğunlukla yavru balıklarda gözlenirken, kronik formu ise daha büyük balıklarda gözlenir. Hastalıktan etkilenen balıklar iştahsız, durgun ve su yüzeyine yakın bir şekilde yüzer. Balıkların vücut yüzeyinde kanamalar mevcut ve yaygin olup, bu kanamalara yüzgeçlerin taban kısımlarında, baş bölgesinde ve yan çizgi boyunca rastlanır (Tobback 2009). Nekropside karaciğer, pilorik seka ve hava kesesi ile lateral vücut kaslarında peteşiyel kanamalar, ascites, dalakta büyüme ve renginde koyulaşma gözlenir. Bağırsak yang1lı olup, opak ve pürülent bir siv1 ile doludur (Tobback 2009). Hastalığın tedavisinde genel olarak amoksisilin, okzalinik asit, oksitetrasiklin, kuvvetlendirilmiş sülfonamidler ve florfenikolün kullanıldığının bildirilmesine karşın, Y. ruckeri de okzalinik asit, oksitetrasiklin ve sülfonamidlere karşı direnç geliştiği yapılan in vitro çalışmalar ile ortaya koyulmuştur (Strand 2017, Zorriehzahra ve ark 2017). Y. ruckeri de gözlenen antibiyotik direnç, araştırmacıları probiyotik, aşılama ve faj tedavisi gibi koruyucu önlemleri araştırmaya yönlendirmiştir (Strand 2017, Zorriehzahra ve ark 2017). Ayrıca, Iran, Hindistan ve Çin gibi birçok ülkede balık patojenlerine karş1 bitkilerde kullanılmaya başlanmış ve Nigella sativa, Olea europea ve Melissa officinalis gibi bitkilerin in vitro koşullarda antibakteriyel etkileri araştırılmıştır (Zorriehzahra ve ark 2017). Deniz fauna ve floras1 içerisinde yer alan algler çeşitli biyolojik aktivitelere sahiptir (Kavsalya ve Narasimha, 2015). Alglerin zengin biyoaktif kaynaklar olarak kabul edilmeleri sebebi ile son yıllarda farmasötik ajan kaynakları şeklinde kullanımları yaygınlaşmıştır (Kavsalya ve Narasimha 2015). Birçok deniz alginin bazı Grampozitif ve Gram-negatif patojenlerin gelişmesini engellediği bildirilmiştir (Kalanjinathan ve ark 2009). Ülkemizde ise çeşitli alg türlerinin Staphylococcus aureus, Escherichia coli ve Enterococcus türleri üzerine antibakteriyel aktiviteleri farklı araştırıcılar tarafından çalışılmıştır (Tüney ve ark 2006, Taşkın ve ark 2007). $\mathrm{Bu}$ çalışmanın amac1 Liagara ceranoides, Halopteris scoparia, Padina pavonica ve Sargassum vulgare alg türlerinin metanol ve etanol ekstraktlarının Y. ruckeri suşları üzerine antibakteriyel aktivitelerini ayrıca çeşitli antibiyotiklere olan duyarlılıklarını da araştırmaktır.

\section{MATERYAL ve METOT}

\section{Balık materyali}

Çalışma Akdeniz Üniversitesi BAP 201101.0111.001 proje kodu ile desteklenip, 2011.10.01 say1 ile A.Ü. Deney Hayvanları Yerel Etik Kurul onayı alınmıştır. Hasta gökkuşağı alabalıkları Antalya civarındaki ticari bir işletmeden temin edilmiştir. İşletmede balıkların bulunduğu havuzların su sıcaklığ1 $15{ }^{\circ} \mathrm{C}$ olarak ölçülmüştür. Çalışmada vücut ağırlıkları 82.9 g'dan 253.44 g'a kadar değişen 10 balıktan örnekleme yapılmıştır. Balıklarda gözlenen diş bulgular kaydedildikten sonra balıklara nekropsi uygulanarak iç bulgular kaydedilmiştir. Bakteriyolojik çalışmalar için balıkların karaciğer, dalak ve ön böbreklerinden beyin kalp infüzyon (BHI) agar'lı besiyerlerine ekimler yapılmıştır. Ekimli besiyerleri $24 \pm 2{ }^{\circ} \mathrm{C}$ de 48 saat süre ile inkübe edilmiştir. $\mathrm{Bu}$ süre sonunda besiyerinde gelişme gösteren yuvarlak, krem-beyaz renkli bakteri kolonilerinden altkültürler hazırlanmıştır.

\section{Bakteri suşlarının fenotipik özelliklerinin tespiti}

İzole edilen bakteri suşlarının fenotipik özelliklerinin tespiti için bir dizi test uygulanmıştır (Roberts 2012). Ayrica, API 20E (BioMerieux, Fransa) hizlı tanı kiti de kullanılmıştır. Kit üretici firmanın önerileri doğrultusunda hazırlanarak, sonuçlar 24-48 saat sonra okunmuştur. Çalışmalara Refik Saydam Hifzısıhha Merkezi Başkanlığı/Ankara'dan temin edilen ATCC 
19570 kodlu Aeromonas bydrophila suşu da dahil edilmiştir.

\section{Polimeraz Zincir Reaksiyonu (PZR)}

Fenotipik tanı test sonuçlarına göre Yersinia ruckeri şüpheli suşların konfirmasyonunda PZR tekniğinden de yararlanılmıştır. Bu amaçla suşlardan DNA izolasyonu InstaGene Matrix (BioRad) marka ticari kit kullanılarak yapılmıştır. İleri ve geri primerler, YER8 (5'-GCGAGGAGGAAGGGT'TAAGTG-3') ve YER10 (5'-GAAGGCACCAAGGCATCTCTG-3') (Gibello ve ark 1999) ticari bir firmaya sentezlettirilmiştir. İlk denatürasyon $94{ }^{\circ} \mathrm{C}$ de 2 dakika, diğerleri ise $94{ }^{\circ} \mathrm{C}$ de 1 dakika, primer bağlanması $55{ }^{\circ} \mathrm{C}$ de 1 dakika ve uzama (polimerizasyon) $72{ }^{\circ} \mathrm{C}$ de 8 dakika olacak şekilde toplam 35 PZR döngüsü gerçekleştirilmiştir (Şeker ve ark 2012). PZR ürünleri $100 \mathrm{~V}$ da 45 dakika yürütülmüş ve yürütme sonrası ürünler görüntülenmiştir. Ürünler $50 \mathrm{ng} / \mathrm{ml}$ yoğunluk ve minimum $20 \mu \mathrm{l}$ olacak şekilde hazırlanmış ve dizi analizi için özel bir laboratuvara gönderilmiştir. Her ürün için DNA saflaştırması ve çift yönlü okuma işlemi yapılarak ham dizi verileri Chromas-Pro 1.7,5 programı ile FASTA formatına çevrilerek temizlenmiş ve tek bir dizi haline getirilmiştir. BLAST analizi uygulaması ile en yakın türler ve benzerlik oranları her bir suş için tespit edilmiştir.

\section{Bakteri suşlarının antimikrobiyal duyarlılıklarının tespiti}

Suşların antimikrobiyal duyarlılıkları Mueller-Hinton Agar (MHA)'lı besiyerleri kullanılarak Kirby-Bauer disk difüzyon yöntemi ile tespit edilmiştir. Ínokulum öncesi sıv1 kültürün bulanıklığ1 McFarland No 0.5 (1$\left.2 \times 10^{8}\right)$ standardı ile standardize edilerek, MHA'lı petri kutularına inoküle edilmiştir. Petri kutuları oda sicaklığında 15-20 dakika bekletildikten sonra besiyeri yüzeyine test edilecek olan ticari diskler yerleştirilmiş ve $24 \pm 2{ }^{\circ} \mathrm{C}$ de 24 ila 28 saat süre ile inkübe edilmiştir. Test sonuçlarına göre suşların çeşitli antibiyotiklere (ampisilin, eritromisin, flumekuin, oksitetrasiklin ve trimetoprim) duyarlılıkları Balta ve ark (2010), CLSI (2006a) ve NCCLS (2003)'e göre belirlenmiştir.

Deniz makroalglerinin antibakteriyel
duyarlılıklarının tespiti
Liagora ceranoides J. V. Lamouroux 1816, Halopteris
scoparia (Linnaeus) Sauvageau 1904, Padina pavonica
(Linnaeus) Thivy in Taylor 1960 ve Sargossum vulgare
C. Agardh 1820 makroalg türlerinin (Tablo 1) etanol
ve metanol ekstraktlarının Y. ruckeri suşları üzerine
antibakteriyel aktiviteleri agar difüzyon yöntemi
kullanılarak in vitro koşullarda çalışılmıştır. Algler
Antalya ve Çanakkale kıyılarından SCUBA dalışları ve
plankton bezlerinden yapılmış ağzı büzgülü torbalar
(70x50 cm) ile toplanmıştır (Şekil 1). Toplanan alg
örnekleri epifitlerinden, içlerinde bulunabilecek kaya,
kum ve çamurdan arındırılmak amaci ile ayıklanıp tatlı

su ile yıkanmıştır. Ayıklanan alg örnekleri direkt güneş 1şı̆̆ına maruz birakılmadan gölge bir alanda kurutulmuştur (Şekil 2). Toplanan alg örneklerinin bir kısmı tayin ve tanımları laboratuvarda yapılmak üzere deniz suyu ile hazırlanmış \%4-6'l1k formaldehit solüsyonunda tespit edilmiştir. Alg materyallerinin tanımlanma çalışması Olympus marka SZX16 model stereo zoom ve BX51 model 1ş1k mikroskopları kullanılarak yapılmıştır. Alglerin etanol ve metanol ekstraktları filtre edilerek örnekler kullanılana kadar $+4{ }^{\circ} \mathrm{C}$ de muhafaza edilmiştir (Akrayi 2012). Alglerin etanol ve metanol ekstraktları Akrayi (2012)'ye göre hazırlanmıştır. Kısaca, alg örnekleri kurutulduktan sonra ögütücü kullanılarak toz haline getirilmiştir. Öğ̈̈tme işlemi, her alg örneği için ayrı ayrı yapılmıştır. Toz haline getirilen örneklerin etanol ekstraktlarını elde edebilmek için $150 \mathrm{ml}$ etanol 15 gram toz haldeki alg örneğine ilave edilerek, kaynama noktasına kadar karıştırılarak 1sıtılmıştır. Daha sonra solüsyon Whatman No 1 filtre kağıdı kullanılarak filtre edilmiştir. Aynı yöntem alglerin metanol ekstraktlarının eldesi için tekrarlanmıştır. 11 Y. ruckeri suşunun 24 saatlik kültüründen 2-3 koloni alınarak 5 ml'lik nutrient buyyona ekimleri yapilarak $24 \pm 2{ }^{\circ} \mathrm{C}$ de 24 saat süre ile inkübe edilmiştir. İnkübasyon sonrası bakteriyel süspansiyonun bulanıklı̆̆1 1x106 olacak şekilde ayarlanmıştır (Akrayi 2012). Süspansiyondan $0.1 \mathrm{ml}$ alınarak nutrient agarlı petri kutularının yüzeyine aşılanmıştır. Daha sonra besiyeri yüzeyine $8 \mathrm{~mm}$ çapında delik açılarak içerisine alglerin etanol ve metanol ekstraktlarından $100 \mu \mathrm{l}$ aktarılarak $24 \pm 2{ }^{\circ} \mathrm{C}$ de 24 saat süre ile inkübe edilmiştir. Bu süre sonunda inhibisyon zon çapları ölçülerek sonuçlar Tüney ve ark (2006) ve Akrayi (2012)'ye göre değerlendirilmiştir. Çalışmada kontrol amaçlı olarak toz haldeki trimetoprim CLSI (M49-A) (2006b) önerileri doğrultusunda çözücü olarak hidroklorik asit kullanılarak stok antibiyotik solüsyonu hazırlanmıștır. Stok antibiyotik solüsyonundan $2 \mathrm{ml}$ alınarak $2 \mathrm{ml}$ sulandirıc1 (steril distile su) kullanılarak dilue edilmiştir. Bu solüsyondan $100 \mu \mathrm{l}$ alınarak ekimli besiyeri yüzeyine açılan $8 \mathrm{~mm}$ çapındaki deliklere aktarılarak $24 \pm 2{ }^{\circ} \mathrm{C}$ de 24 saat süre ile inkübe edilmiştir. $\mathrm{Bu}$ süre sonunda inhibisyon zon çap1 ölçülerek sonuçlar değerlendirilmiştir (NCCLS 2003).

\section{BULGULAR}

\section{Klinik bulgular}

Hastalıktan etkilenen balıklarda durgunluk, yem alımında azalma, pul kaybı, deri renginde koyulaşma, solungaçlarda solgunluk, gözde, çenelerde, ağızda, yutak ve dilde hemorajiler (Şekil 3), anüs etrafinda hemoraji ve abdominal dropsi tespit edilmiştir. Nekropsi de vücut kasında, hava kesesi cidarında, pilorik seka ve karaciğerde hemoraji, karaciğerde büyüme ile dalak renginde koyulaşma gözlenmiştir. Hasta balıklarda mide bağırsak içeriği gida yönünden boş olup, sarımsı renkli asidik sıvı içerdiği tespit edilmiştir. 
Yersinia ruckeri suşunun bakteriyolojik ve moleküler tanımlanması

Çalışmada izole edilen 11 suşun Gram-negatif, sitokrom oksidaz negatif, katalaz pozitif, $24{ }^{\circ} \mathrm{C}$ de hareketli iken $37{ }^{\circ} \mathrm{C}$ de hareketsiz olduğu, nonhemolitik, fruktoz, galaktoz, glükoz, mannitol ve mannozdan asit üretirken, arabinoz, inositol ve ksilozdan asit üretmediği tespit edilmiştir. Suşlar Yersinia selektif besiyerinde pembe-kırmız1 renkli koloniler meydana getirirken, Shotts Waltman (SW) besiyerinde ise etrafinda buzlu cam görünümünde olan yeşil renkli kolonileri olușturdukları saptanmıștır (Tablo 2). Çalışmada suşların API 20E profilleri 5104100/77 olarak bulunmuştur. Bu profilin $Y$. ruckeri için bildirilen profil ile uyumlu olduğu anlaşılmıştır. PZR çalışması sonrası oluşan ürünler $\% 1$ lik agaroz jele yüklenerek elektroforez ile yürütülmüş ve UV altında görüntülenen jelde suşların 589 bç'lik amplikon çoğaltımları tespit edilmiştir (Şekil 4). BLAST analizi uygulaması ile en yakın türler ve benzerlik oranları her bir suş için tespit edilmiş ve suşların Y. ruckeri ile olan dizi benzerliği \%100 olarak bulunmuştur.

\section{Suşların antimikrobiyal duyarlılıkları}

Antibiyogram test sonuçlarina göre, 11 suşun Ampisilin'e (inhibisyon zon çap1 20 mm'den 26 mm'e kadar değişmiștir), Trimetoprim'e (inhibisyon zon çap1 16 mm'den 20 mm'e kadar değișmiştir), Flumekuin (inhibisyon zon çap 30 mm'den 40 mm'ye kadar değişmiştir) ve Oksitetrasiklin'e (inhibisyon zon çap1 29 mm'den 34 mm'ye kadar değişmiştir) duyarlı oldukları, Eritromisin'e ise (inhibisyon zon çap1 17 mm'den 20 mm'e kadar değişmiştir) orta derecede dirençli oldukları bulunmuştur (Tablo 3).

\section{Deniz makroalglerinin antibakteriyel aktiviteleri}

L. ceranoides (Rhodophyta), H. scoparia (Ocrophyta), P. pavonica (Ocrophyta) ve $S$. vulgare (Ocrophyta) alglerinin etanol ve metanol ekstraktlarınin Y. ruckeri suşlar1 üzerine antibakteriyel aktiviteleri değerlendirildiğinde, yukarıda belirtilen dört alge ait metanol ekstraktlarının suşlar üzerine etkili olmadığ1 anlaşılmıştır. P. pavonica'nın etanol ekstraktının ise düşük inhibitör aktiviteye $(10 \mathrm{~mm})$ sahip olduğu ancak $L$. ceranoides, $H$. scoparia ve $S$. vulgare'nin etanol ekstraktlarının ise bakteri üzerinde etkili olmadığ1 tespit edilmiștir. Suşlar kontrol amaçlı olarak çalışmaya dahil edilen Trimetoprim'in \%1'lik konsantrasyonuna karşı hassasiyet gösterdiği (inhibisyon zon çap1 20 mm'den 32 mm'ye kadar değişmiştir) bulunmuştur (Tablo 4).

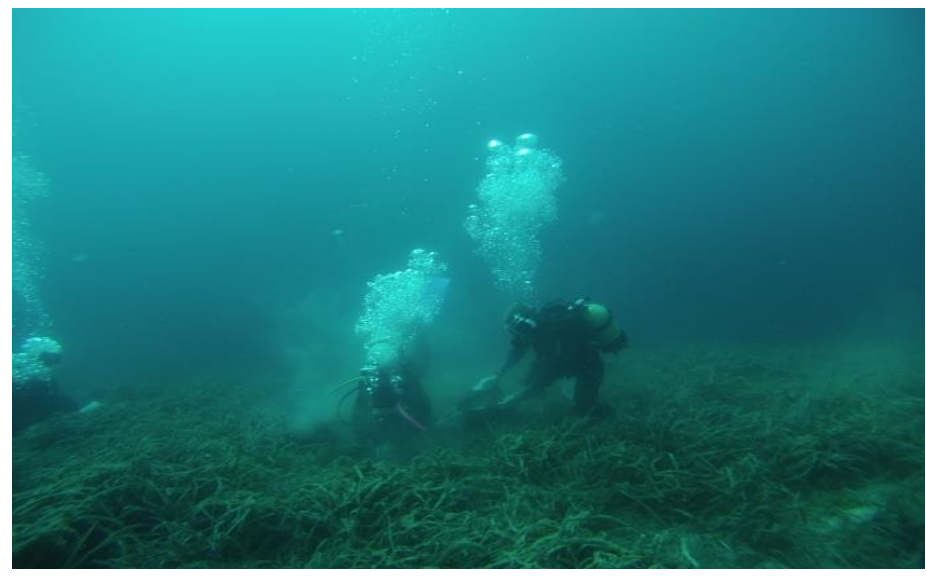

Şekil 1. Makroalglerin SCUBA dalışı ile toplanması

Figure 1. Collection of macroalgea by using SCUBA diving

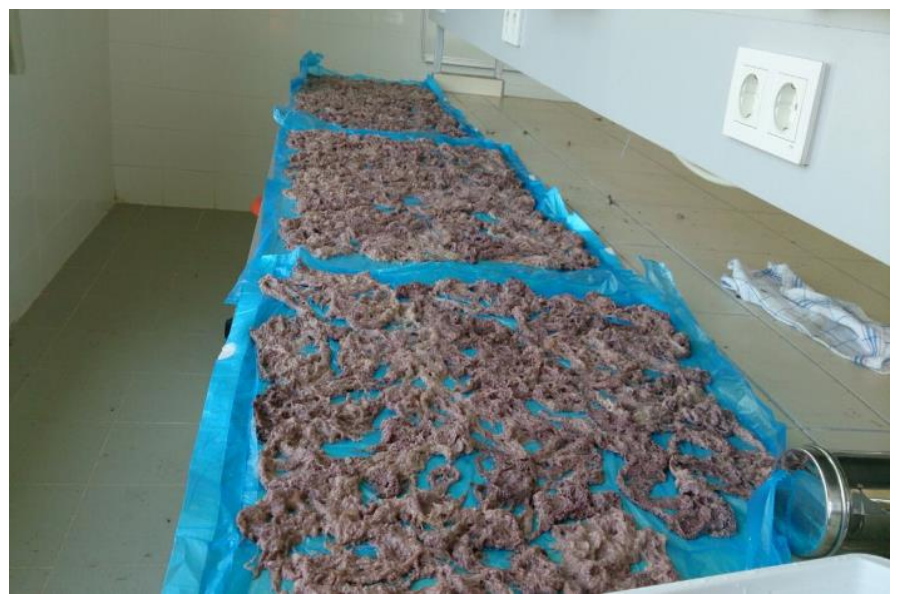

Şekil 2. Makroalglerin kurutulma işlemi

Figure 2. Drying process of macroalgae 


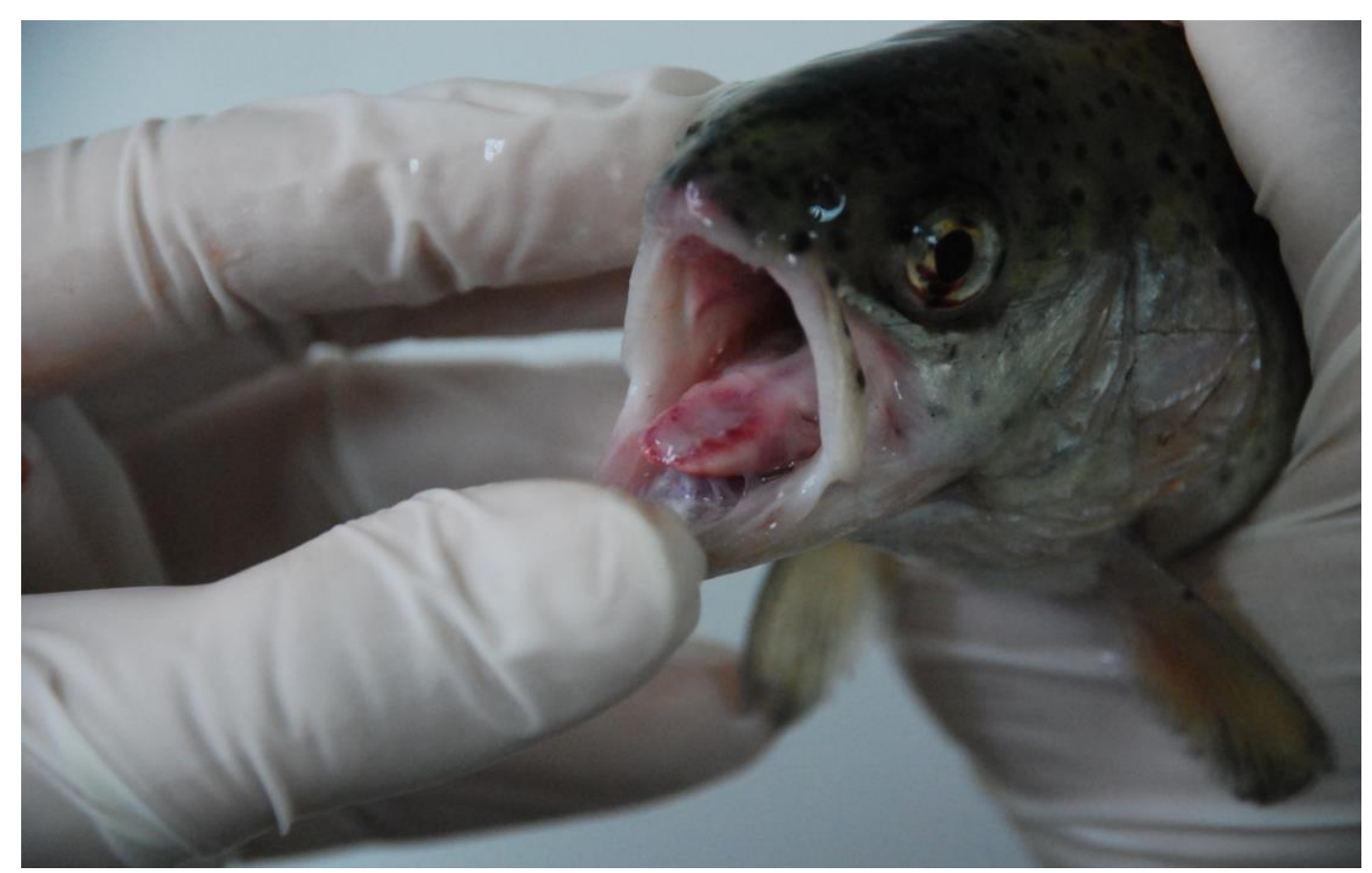

Şekil 3. Y. ruckeri ile enfekte balıklarda ağızda ve dil üzerinde hemoraji

Figure 3. Hemorrhages on the tongue and mouth of the fish infected with Y. ruckeri

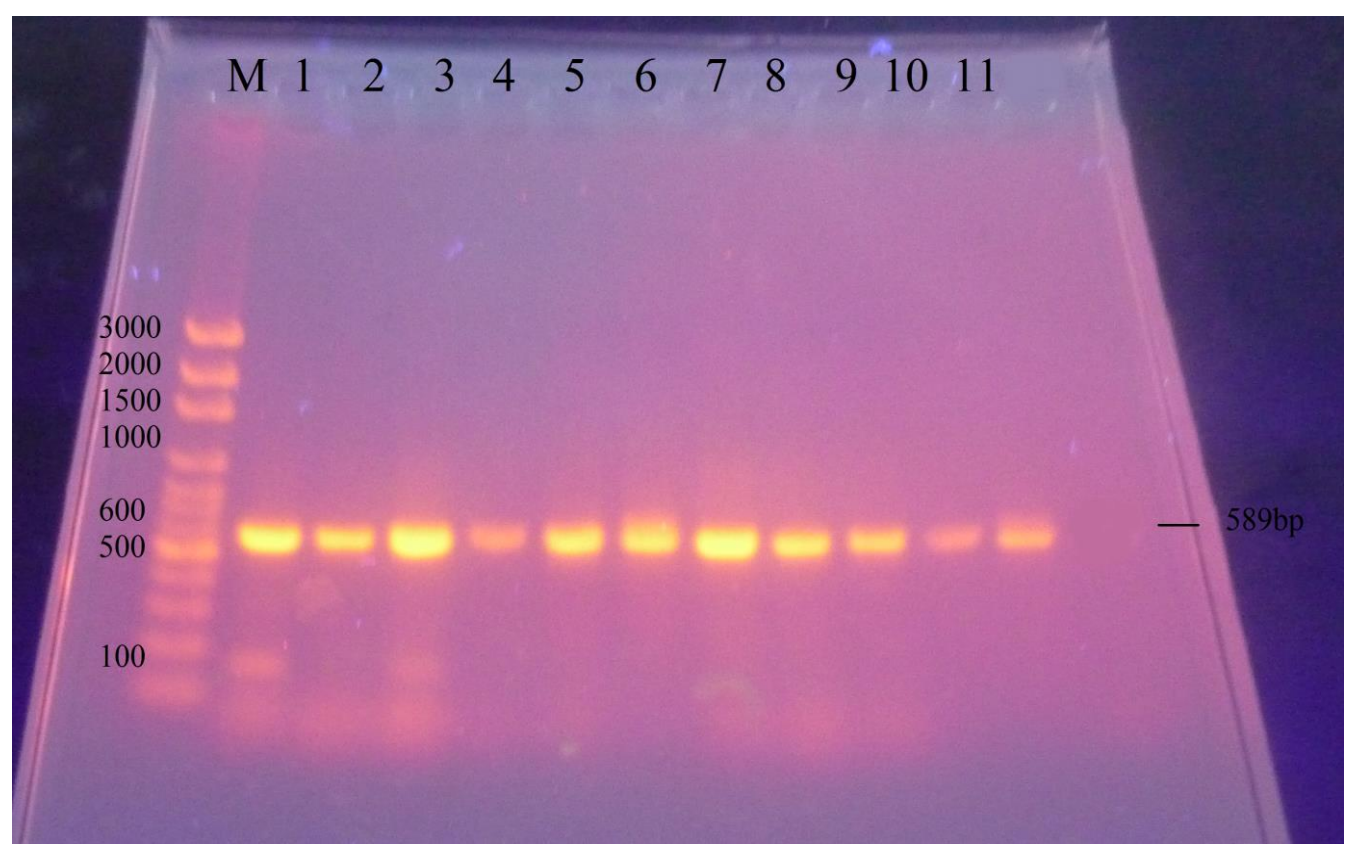

Şekil 4. 11 Y. ruckeri suşunda gözlenen 589 bç'lik bant oluşumu. M: marker.

Figure 4. 589 bp band formation observed in 11 Y. ruckeri strains. M: marker.

Tablo 1. Çalışmada kullanılan makroalgler.

Table 1. Macroalgae used in the study.

\begin{tabular}{llll}
\hline Tür adı & Şehir & Koordinat & Derinlik (m) \\
\hline Rhodophyta & & $36^{\circ} 52^{\prime} 57.15^{\prime \prime} \mathrm{K}$ & \\
Liagora ceranoides & Antalya & $30^{\circ} 40^{\prime} 40.36^{\prime \prime} \mathrm{D}$ & $0-5$ \\
Ocrophyta & & $40^{\circ} 7^{\prime} 34.96^{\prime \prime} \mathrm{K}$ & \\
Halopteris scoparia & Çanakkale & $26^{\circ} 20^{\prime} 49.84^{\prime \prime} \mathrm{D}$ & $0-1$ \\
& & \\
Padina pavonica & Antalya & $36^{\circ} 49^{\prime} 59.84^{\prime \prime} \mathrm{K}$ & $5-20$ \\
Sargassum vulgare & Antalya & $31^{\circ} 7^{\prime} 28.67^{\prime \prime} \mathrm{D}$ & \\
& &
\end{tabular}


Tablo 2. Hasta balıklardan izole edilen Yersinia ruckeri suşlarının fenotipik özellikleri

Table 2. Phenotypic characteristics of the Yersinia ruckeri strains isolated from diseased fish

\begin{tabular}{|c|c|c|c|}
\hline Testler & Y. ruckeri suşları & Y. ruckeri & A. hydrophila \\
\hline & (11 suş) & (Austin ve Austin, 2012) & (ATCC 19570) \\
\hline Gram boyama & - & - & - \\
\hline \multicolumn{4}{|l|}{ Hareket } \\
\hline $24^{\circ} \mathrm{C}$ & + & + & + \\
\hline $30^{\circ} \mathrm{C}$ & + & & + \\
\hline $37^{\circ} \mathrm{C}$ & - & & - \\
\hline Sitokrom oksidaz & - & - & + \\
\hline Katalaz & + & + & + \\
\hline $\mathrm{O} / \mathrm{F}$ & $\mathrm{F}$ & $\mathrm{F}$ & $\mathrm{F}$ \\
\hline $\mathrm{H}_{2} \mathrm{~S}$ & - & - & - \\
\hline Sitrat & $\mathrm{D}$ & + & - \\
\hline onpg* & $\mathrm{D}$ & + & + \\
\hline İndol & + & - & + \\
\hline MR & + & + & + \\
\hline VP & - & - & - \\
\hline Arjinin dihidrolaz & + & & - \\
\hline Lizin dekarboksilaz & + & + & - \\
\hline Ornitin dekarboksilaz & + & + & - \\
\hline \multicolumn{4}{|c|}{ Şekerlerden asit üretimi } \\
\hline Arabinoz & - & & + \\
\hline Fruktoz & + & + & - \\
\hline Galaktoz & + & & - \\
\hline Glukoz & + & + & + \\
\hline İnositol & - & - & - \\
\hline Ksiloz & - & & - \\
\hline Mannitol & + & + & - \\
\hline Mannoz & + & & + \\
\hline Sorbitol & $\mathrm{D}$ & - & - \\
\hline Sukroz & - & - & - \\
\hline Tween80 hidrolizi & + & - & \\
\hline Jelatin indirgeme & + & + & + \\
\hline Nişasta indirgeme & $\mathrm{D}$ & & + \\
\hline \multicolumn{4}{|c|}{ Farklı tuzluluklarda gelişme } \\
\hline$\% 0 \mathrm{NaCl}$ & + & + & + \\
\hline$\% 2 \mathrm{NaCl}$ & + & + & + \\
\hline$\% 4 \mathrm{NaCl}$ & + & & + \\
\hline$\% 6 \mathrm{NaCl}$ & + & & + \\
\hline$\% 8 \mathrm{NaCl}$ & - & & + \\
\hline \multicolumn{4}{|c|}{ Farklı sıcaklıklarda gelişme } \\
\hline $24^{\circ} \mathrm{C}$ & + & & + \\
\hline $30{ }^{\circ} \mathrm{C}$ & + & & + \\
\hline $37^{\circ} \mathrm{C}$ & + & & + \\
\hline Nitratı indirgeme & + & + & + \\
\hline
\end{tabular}

+: pozitif, -: negatif, F: fermentatif, onpg: Orto-Nitrofenil-ß-Galaktozid 
Tablo 3. Çalışmada izole edilen 11 Y. ruckeri suşunun standart disk difüzyon testine göre antibiyotik duyarlllik sonuçları

Table 3. Antibiotic sensivity results of $11 \mathrm{Y}$. ruckeri strains isolated in the study according to the standard disk diffusion test.

\begin{tabular}{|c|c|c|c|c|}
\hline \multirow[t]{2}{*}{ Antibiyotikler } & \multicolumn{3}{|c|}{ Zon çap1* } & \multirow[t]{2}{*}{ Suşlar (11 suş) } \\
\hline & $\bar{D}$ & I & $\mathbf{H}$ & \\
\hline Ampisilin $(10 \mu \mathrm{g})^{\mathrm{a}}$ & $\leq 13$ & $14-16$ & $\geq 17$ & $\mathrm{H}$ \\
\hline Eritromisin $(15 \mu \mathrm{g})^{\mathrm{b}}$ & $\leq 13$ & $14-22$ & $\geq 23$ & $\mathrm{I}$ \\
\hline Flumekuin $(30 \mu \mathrm{g})$ & d & & & \\
\hline Oksitetrasiklin $(30 \mu \mathrm{g})^{\mathrm{b}}$ & $\leq 14$ & $15-18$ & $\geq 19$ & $\mathrm{H}$ \\
\hline Trimetoprim $(5 \mu \mathrm{g}) \mathrm{c}$ & $\leq 13$ & $14-16$ & $\geq 17$ & $\mathrm{H}$ \\
\hline
\end{tabular}

Tablo 4. Rhodophyta ve Ocrophyta üyesi alglerin Y. ruckeri üzerine antibakteriyel aktiviteleri

Table 4. Antibacterial activities of algae of members of Rhodophyta and Ocrophyta on Y. ruckeri

\begin{tabular}{lll}
\hline Rhodophyta & Çözücü & $\mathbf{1 1 ~ Y . ~ r u c k e r i ~ s u s ̧ u ~}$ \\
\hline L. ceronoides & metanol & - \\
H. scoparia & metanol & - \\
S. vulgare & metanol & - \\
\hline Ocrophyta & & \\
\hline P.pavonica & metanol & - \\
\hline Rhodophyta & & \\
\hline L. ceronoides & etanol & - \\
H. scoparia & etanol & - \\
S. vulgare & etanol & - \\
\hline Ocrophyta & & $+(10 \mathrm{~mm})$ \\
\hline P. pavonica & etanol & \\
\hline
\end{tabular}

-: aktivite tespit edilmemiştir; +: düşük aktivite (10 mm zon çapı)

\section{TARTIŞMA}

Algler polisakkarit, tannin, flavoidler, fenolik asit, bromfenoller ve karetonoidler gibi bileşiklerin önemli kaynakları olmakla birlikte, bu bileşiklerin farklı çözücüler ile eriyebilme özelliklerine ve polaritelerine göre farklı antimikrobiyal aktivite gösterdikleri bildirilmiştir (Kausalya ve Narasimha, 2015). Bu nedenle, mevcut çalışmada L. ceranoides (Rhodophyta), H. scoparia (Ocrophyta), P. pavonica (Ocrophyta) ve $S$. vulgare (Ocrophyta) makroalglerinin etanol ve metanol esktraktlarının hasta gökkuşağı alabalıklarından izole edilen $Y$. ruckeri suşları üzerine antibakteriyel aktiviteleri araştırılmıştır. Ayrıca, suşların çeşitli antibiyotiklere olan duyarlılıkları da incelenmiştir.

Çalışmada yersiniozisden etkilenen balıklarda iştahsızlı, deri renginde koyulaşma, solgun solungaçlar, alt ve üst çenelerde, dilde, yüzgeçlerin taban kısımlarında, gözde ve anüs etrafinda ve iç organlarda hemorajiler, karaciğerde büyüme ve dalak renginde koyulaşma tespit edilerek, bu bulguların diğer araştırmacıların (Mahjoor ve Akhlaghi 2012, Orozova ve ark 2014) bulguları ile benzerlik gösterdiği anlaşılmıştır.

Yapılan çalışmada suşların Gram-negatif, fermentatif, sitokrom oksidaz negatif ve katalaz pozitif olduğu,
Tween 80'i hidrolize ettikleri, Yersinia selektif besiyerinde pembe kırmızı renkli koloni oluştururken, SW besiyerinde ise etrafinda buzlu cam görünümü olan yeşil renkli kolonileri oluşturdukları tespit edilmiştir.

Altun ve ark (2010) izole ettikleri Y. ruckeri suşlarının sitokrom oksidaz negatif, katalaz pozitif, fermentatif olduğunu, SW besiyerinde yeşil renkli kolonileri oluşturduğunu ve bu kolonilerin etrafinda buzlu cam görünümünde zon geliştiğini ve suşların Tween 80’i hidrolize ettiğini bildirmiştir.

Çalışmada uygulanan PZR tekniği sonrası ürünler $\% 1$ 'lik agaroz jele yüklenerek elektroforez de yürütülmüştür. Görüntülemede $11 Y$. ruckeri suşunun tümünde 598 bç'lik amplikon çoğaltımının yapıldığı gözlenmiștir. Elde edilen bu bulguların, Șeker ve ark (2012) tarafindan Y. ruckeri için bildirilen 589 bç'lik moleküler büyüklüğe sahip pozitif örnekler ile uyumlu olduğu anlaşılmıştır.

Yersinia cinsi üyeleri için eritromisine karşı doğal direnç bildirilmekle birlikte, Y. ruckeri’nin genellikle ampisilin, flumekuin, oksitetrasiklin ve trimetoprime duyarlı olduğu bildirilmiştir (Calvez ve ark. 2014). Orozova ve ark (2014) Bulgaristan da yersinozisden etkilenen balıklardan izole ettikleri suşların eritromisin 
dışında ampisilin, flumekuin, oksitetrasiklin ve trimetoprime duyarl, eritromisine ise orta derecede dirençli olduğunu tespit etmiştir. Ülkemiz de ise Balta ve ark (2010) çalışmalarında $Y$. ruckeri suşlarının oksitetrasikline en yüksek direnci gösterdiğini, bu direnci sırası ile ampisilin ile okzalinik asidin izlediğini, suşların en düşük direnci ise enroflaksozine gösterdiğini bildirmiştir. Mevcut çalışmada Balta ve ark (2010) ile Orozova ve ark (2014) tarafindan Y. ruckeri için bildirilen eritromisine direnç, orta direnç şeklinde tespit edilirken, suşların Calvez ve ark (2014) tarafindan bildirildiği gibi ampisilin, flumekuin, oksitetrasiklin ve trimetoprime duyarlı olduğu bulunmuştur.

L. ceranoides (Rhodophyta), H. scoparia (Ocrophyta), P. pavonica (Ocrophyta) ve $S$. vulgare (Ocrophyta) makroalglerinin etanol ve metanol ekstraktlarının $Y$. ruckeri üzerine antibakteriyel aktiviteleri değerlendirildiğinde, yukarıda bahsedilen dört alge ait metanol ekstraktlarının $Y$. ruckeri üzerine antibakteriyel yönden etkili olmadığı anlaşılmıştır. $P$. pavonica'nin etanol ekstraktının $Y$. ruckeri üzerinde düşük inhibitör aktiviteye $(10 \mathrm{~mm})$ sahip olduğu ancak $L$. ceranoides, $H$. scoparia ve $S$. vulgare'nin etanol ekstraktlarının ise bakteri üzerinde antibakteriyel yönden etkili olmadığ1 görülmüştür. Çalıșmada suşların kontrol amaçlı trimetoprim'in \%1'lik konsantrasyonuna karşı duyarlılık gösterdiği tespit edilmiştir (inhibisyon zon çap 20 mm'den 32 mm'ye kadar değişmiştir). Taşkın ve ark (2007) çalışmalarında Rhodophyta (Corallina officinalis Linnaeus 1758), Ocrophyta (Cystoseira barbata (Stackhouse) C.Agardh 1820, Dictyota dichotoma (Hudson) J.V.Lamouroux 1809, Halopteris filicina (Grateloup) Kützing 1843, Cladostephus spongiosum $f$. verticillatum (Lightfoot) Prud'homme van Reine 1972) ve Chlorophyta (Ulva rigida C.Agardh 1823)'ye ait deniz alglerinin metanol ekstraktlarının in vitro olarak Gram-negatif ve Grampozitif bakteri türleri üzerine antibakteriyel etkileri çalışmışlardır. Çalışma sonuçlarına göre, C. officinalis dişında diğer alg türlerinin Staphylococcus aureus üzerine inhibisyon aktivite göstermiştir. Tüney ve ark (2006) çalışmalarında P. pavonica'nın etanol ekstraktlarının Candida sp., Enterococcus faecalis, S. aureus ve Escherichia colìye karşı zayıf aktivite gösterdiğini bildirirken, $P$. pavonica'nın metanol ekstraktlarının ise antibakteriyel veya antifungal aktivite göstermediğini bildirmiştir. Gonzalez del Val ve ark (2001) 82 deniz alginin antimikrobiyal aktivitelerini araştırdıkları çalışmalarında, Ocrophyta üyelerinin \%84'ünün, Rhodophyta üyelerinin \%67'sinin ve Chlorophyta üyelerinin \%44'ünün üç gram-pozitif, iki gram-negatif ve bir maya türü üzerine etkili olduğunu, $P$. pavonica'nın sadece metanol ekstraktının B. subtilis üzerine etkili olduğunu bildirmiştir. Çalışmamızda Gonzalez del Val ve ark (2001)'nın bildirdiğine benzer olarak Ocrophyta üyesi $P$. pavonica'nın etanol ekstraktı $Y$. ruckerìye karş1 düşük aktiviteye sahip iken, aynı aktivite Rhodophyta üyesi $L$. ceranoides'in etanol ekstraktında tespit edilememiştir. Çalışmamızda $P$. pavonica'nın etanol ekstraktının $Y$. ruckerìye karşı düşük aktivite göstermesi yönünden Tüney ve ark (2006)'nın sonuçları ile benzerlik gösterdiği ancak Gonzalez del Val ve ark (2001)'nın sonuçları ile farklılık gösterdiği anlaşılmıştır.

Sonuç olarak, alglerin antibakteriyel aktivitelerinin bulunduğunun bildirilmesine karşın, mevcut çalışmada ve diğer çalışmalarda da olduğu gibi her alg türünün antibakteriyel aktivite gösteremeyeceği, bu durumun ise kullanılan çözücü ve alg türüne göre değişiklik gösterebileceği anlaşılmıştır.

\section{TEŞEKKÜR}

Calısma Akdeniz. Üniversitesi BAP 201101.0111.001 proje kodu ile desteklenmis, çalısmanm bir kısmı Doğu Anadolu Bölgesi 5. Su Ürünleri Sempozyumu'nda sunulmus, Akdeniz. Unniversitesi Hayvan Deneyleri Yerel Etik Kurulu tarafindan 2011. 10.01. protokol numarasi ile Etik Kurul onayı alınarak gerçekleştirilmiștir.

\section{KAYNAKLAR}

Akrayi HFS. Effect of some plant extracts on isolated bacteria from eyelids of natural eye liner users and eye cosmetics users. JAPS. 2012; 2(11): 003-008.

Altun S, Kubilay A, Diler Ö. Yersinia ruckeri suşlarının fenotipik ve serolojik özelliklerinin incelenmesi. Kafkas Univ Vet Fak Derg. 2010. 16; Suppl-B: 223-229.

Austin B, Austin DA. Bacterial fish pathogens; diseases of farmed and wild fish. Springer, 2012, New York, London.

Balta F, Sandalı C, Kayış S, Özgümüş OB. Molecular analysis of antimicrobial resistance in Yersinia ruckeri strains isolated from rainbow trout (Oncorbynchus mykiss) grown in commercial fish farms in Turkey. Bull Eur Ass Fish Pathol. 2010; 30(16): 211-219.

Balta F, Balta ZD, Özgümüş OB, Çağırgan H. Doğu Karadeniz Bölgesi’ndeki gökkuşağı alabalığ1 (Oncorbynchus mykiss) çiftliklerinde Yersinia ruckerı'nin portörlük yönünden tetkiki ve antimikrobiyal direncin tespiti. Anadolu Çevre ve Hayvancıllk Bilimleri Dergisi. 2016; 1(3): 72-76

Calvez S, Gantelet H, Blanc G, Dovet DG, Daniel P. Yersinia ruckeri biotypes 1 and 2 in France: presence and antibiotic susceptibility. Dis Aquat Org. 2014; 109: 117-126.

CLSI (Clinical and Laboratory Standards Institute). Methods for antimicrobial disk susceptibility testing of bacteria isolated from aquatic animals; Approved Guideline. CLSI Document M42-A. 2006a, USA.

CLSI (Clinical and Laboratory Standards Institute). Methods for broth dilution susceptibility testing of bacteria isolated from aquatic animals; Approved Guideline. CLSI document M49-A. 2006b, USA.

Fouz B, Zarza C, Amaro C. First description of non-motile Yersinia ruckeri serovar I strains causing disease in rainbow trout, Oncorbynchus mykiss (Walbaum), cultured in Spain. Journal of Fish Diseases. 2006; 29: 339-346.

Gibello A, Blanco MM, Moreno MA, Cutuli MT, Domenech A, Domínguez L, Fernández-Garazábal JF. Development of a PCR assay for detection of Yersinia 
ruckeri in tissues of inoculated and naturally infected trout. Appl Environ Microbiol. 1999; 65: 346-350.

Gohari M, Sharifiyazdi H, Akhlaghi M. Detection of Yersinia ruckeri in rainbow trout (Oncorbynchus mykiss) fry tissues, using bacterial culture, simple PCR and nested PCR. Bull Eur Assoc Fish Pathol. 2010; 30(5): 177-184.

Gonzalez del Val A, Platas G, Basilic A, Cabello A, Garrochategui J, Suay I, Vicente F, Portillo E, Jimenez Del Rio M, Reina GG, Peleaz F. Screening of antimicrobial activities in red, green and brown macro algae from Gran Canaria (Canary Islands, Spain). Int Microbiol. 2001; 4: 35-40.

Horne MT, Barnes AC. Enteric red mouth disease (Yersinia rucker $)$. In: Fish Diseases and Disorders-Viral, Bacterial and Fungal Infections, Ed: Woo PTK, Bruno DW., CABI Publishing, UK. 1999; pp. 455-477.

Huang Y. Runge M, Michael GB, Schwarz S, Jung A, Steinhagen D. Biochemical and molecular heterogeneity among isolates of Yersinia ruckeri from rainbow trout (Oncorbynchus mykiss, Walbaum) in north west Germany. BMC Vet Res. 2013; 9: 215-224.

Kausalya M, Narasimha Rao GM. Antimicrobial activity of marine algae. J Algal Biomass Utln. 2015; 6(1): 78-87.

Kolanjinathan K, Ganesh P, Govindarajan M. Antibacterial activity of ethanol extracts of seaweeds against fish bacterial pathogens. Eur Rev Med Pharmacol Sci. 2009; 13: $173-177$

Kumar G, Menanteau-Ledouble S, Saleh M, El-Matbouli M. Yersinia ruckeri, the causative agent of enteric redmouth disease in fish. Vet Res. 2015;46: 103-113

Mahjoor AA, Akhlaghi M. A pathological study of rainbow trout organs naturally infected with enteric red mouth. Asian J Anim Sci. 2012; 6(3): 147-153.

NCCLS (National Committee for Clinical Laboratory Standards). Disk Difüzyon Ek Tablolar. M100-S13 (M2), Türk Mikrobiyoloji Cemiyeti, İstanbul.

Orozova P, Chikova V, Sirakov I. Diagnostics and antibiotic resistance of Yersinia ruckeri strains isolated from trout fish farms in Bulgaria. IJDR. 2014; 4(12): 2727-2733.

Öztürk RÇ, Altınok İ. Bacterial and viral fish diseases in Turkey. Turk J Fish Aquat Sci. 2014; 14: 275-297.

Roberts RJ. The Bacteriology of Teleosts, In: Fish pathology, Ed: Roberts RJ, 4th Ed., Blackwell Publishing Ltd, UK. 2012; pp. 339-382.

Strand A. Analyses of bacteriophages to Yersinia ruckeri and the salmon (Salmo salar L.) antibody response to the bacteriophages. MSc. Thesis, Master of Science in Aquamedicine. University of Bergen, Norway, 2017.

Şeker E, Karahan M, Sarıeyyüpoğlu M, Çetinkaya B. Detection of Yersinia ruckeri by polymerase chain reaction (PCR) in infected rainbow trout (Oncorbynchus mykiss, Walbaum 1792). J Anim Plant Sci. 2011; 21(8): 570-574.

Şeker E, Karahan M, İspir Ü, Çetinkaya B, Sarıeyyüpoğlu M. Investigation of $Y$. ruckeri infection in rainbow trout (Oncorbynchus mykiss, Walbaum 1792) farms by polymerase chain reaction (PCR) and bacteriological culture. Kafkas Univ Vet Fak Derg. 2012; 18(6): 913-916.

Taşkın E, Öztürk M, Taşkın E, Kurt O. Antibacterial activities of some marine algae from the Aegean Sea (Turkey). Afr J Biotechnol. 2007; 6(24): 2746-2751.

Timur G, Timur M. An outbreak of enteric red mouth disease in farmed rainbow trout (O. mykiss) in Turkey. Bull Eur Assoc Fish Pathol. 1991; 11(5): 182-183.
Tobback E. Early pathogenesis of Yersinia ruckeri infections in rainbow trout (Oncorbynchus mykiss, Walbaum). Ph. Thesis, Veterinary Sciences, Faculty of Veterinary Medicine, Ghent University, Ghent, 2009.

Tüney İ, Çadırcı BH, Ünal D, Sukatar A. Antimicrobial activities of the extracts of marine algae from the coast of Urla (İzmir, Turkey). Turk J Biol. 2006; 30: 171-175.

Zorriehzahra MJ, Adel M, Tarabi Delshad S. Enteric redmouth disease: past, present and future: a review. IJFS. 2017; 16(4): 1135-1156. 